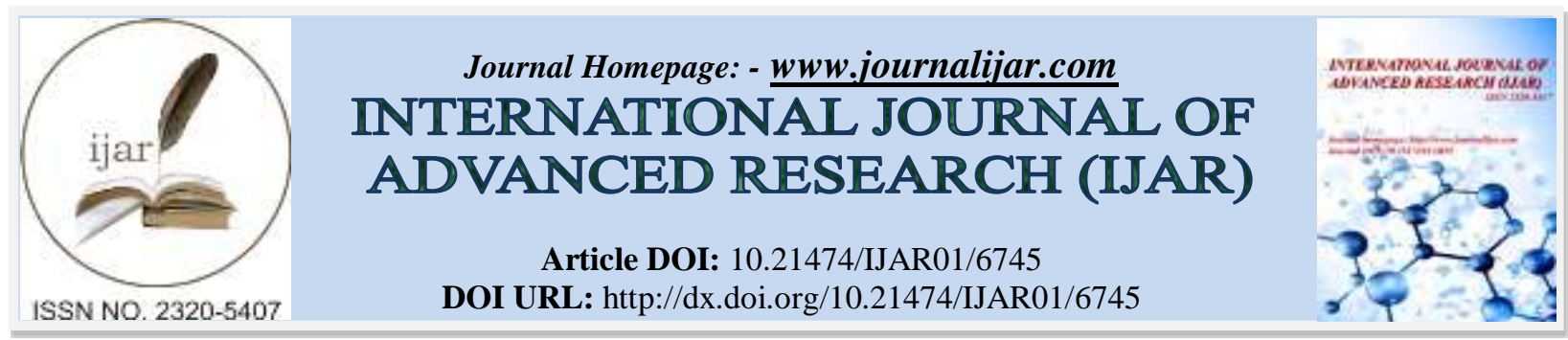

RESEARCH ARTICLE

\title{
TRIAL BY MEDIA: CONCEPT AND PHENOMENON.
}

\section{Dr. S. Krishnan.}

Assistant Professor, Seedling School of Law and Governance, Jaipur National University. The writer worked as an

Assistant Professor in Apex Professional University, Pasighat, Arunachal Pradesh. He also had worked as a Journalist in esteemed newspapers like Indian Express and DNA, online newsportals and a magazine in Ahmedabad. He also had worked as a Liaison Officer in Indian Society of International Law, New Delhi

\section{Manuscript Info}

\section{Manuscript History}

Received: 14 January 2018

Final Accepted: 16 February 2018

Published: March 2018

Keywords:-

Freedom of speech, Media, Judiciary.

\begin{abstract}
A media shackled by its government is an unhealthy thing; however, a media allowed to run its mouth in an unaccountable manner may prove to be even more dangerous. While there must be punishments for the heinous crimes committed every day, the process of punishment should not encroach on the right of the accused for a free and fair trial in a Court of law. The problem of media trials is becoming more and more prevalent today. This article tries to analyse the problem of media trials by studying the various materials available on the topic, such as newspaper articles on the most famous media trials of India. I have come to the conclusion, after a fair analysis, that while the freedom of the press must be maintained in a country governed by the principle of "rule of law", there must be a certain restraint to prevent the media from encroaching on the sole jurisdiction of the Courts of law i.e., the administration of justice.
\end{abstract}

Copy Right, IJAR, 2018,. All rights reserved.

\section{Introduction:-}

Media has always been considered the watchdog of the society. It is very important to have a free and fair media in every form of government. In a vast and diverse democracy like India, it is of utmost importance that the media functions without any form of bias and prejudice as the media also takes the role of the Opposition. Media is almost like the backbone of the Indian democracy. The roots of media can be traced back to the times of the Nationalist Movement in India. Ever since those times, media has been a crucial role in guaranteeing the citizens their rights and liberties. Besides playing these important roles, media has evolved as a much needed agent of change in the society. Over the years, media has helped to form public opinion and has been quite successful in this role. The role of media in a democracy comes into focus especially during the ongoing process of elections in India. The different types of media (television, radio, etc.) have helped the masses to be more educated and aware of their surroundings. Investigative journalism is a type of journalism that is much into practice, these days. Media is regarded as one of the pillars of democracy. Media has wide ranging roles in the society. Media plays a vital role in molding the opinion of the society and it is capable of changing the whole viewpoint through which people perceive various events. The media can be commended for starting a trend where the media plays an active role in bringing the accused to hook.

Freedom of media is the freedom of people as they should be informed of public matters. It is thus needless to emphasis that a free and a healthy press is indispensable to the functioning of democracy. In a democratic set up 
there has to be active participation of people in all affairs of their community and the state. It is their right to be kept informed about the current political social, economic and cultural life as well as the burning topics and important issues of the day in order to enable them to consider forming broad opinion in which they are being managed, tackled and administered by the government and their functionaries. To achieve this objective people need a clear and truthful account of events, so that they may form their own opinion and offer their own comments and viewpoints on such matters and issues and select their future course of action. The right to freedom of speech and expression in contained in article 19 of the constitution. However the freedom is not absolute as it is bound by the sub clause (2) of the same article. However the right it freedom and speech and expression does not embrace the freedom to commit contempt of court.

Investigative journalism has been a controversial issue ever since it was practiced. Although this type of journalism raises several questions regarding journalistic ethics and rules; nevertheless, this type of journalism has radically helped to shape public opinion. Although the main areas of investigative journalism mainly revolve around the areas of scandals, crime, politics, corruption, etc; this particular journalistic style is not just restricted to the above mentioned fields. In India, investigative journalism came into popular existence in the 1980's. The Bofor's scandal in which the then Indian Prime Minister, Rajiv Gandhi, was accused; was the first instance when investigative journalism came into focus. This scandal later on led Gandhi's defeat in the next elections. This scandal and the type of reporting done by the media made the country take notice of a new form of journalism that was previously employed by magazines and journals. Nowadays, investigative journalism is mostly related with sting operations. Even today, sting operations are widely carried out to report against corrupt ministers and the political setup of the nation. The Tehelka scam raised a lot of uncomfortable questions about the Indian government, but it did help in the citizens in forming their opinions about the malpractices of the Indian government and the corrupt politicians. Many a times, it has been seen that due to the interference of the media, certain cases have got pushed into the limelight which in turn attracts the attention of the masses. Media employs several tactics (debates, discussions, talk shows, etc) to help bring these critical issues into the public sphere thus helping people to get their rights. This has often led to aggrieved parties getting much needed justice. This role of the media is discussed with the help of two case studies.

Some famous criminal cases that would have gone unpunished but for the intervention of media are PriyadarshiniMattoo case, Jessica Lal case, NitishKatara murder case and Bijal Joshi rape case.

The media however drew criticism in the reporting of murder of AarushiTalwar, when it preempted the court and reported that her own father Dr. Rajesh Talwar, and possibly her mother NupurTalwar were involved in her murder. The media has again come in focus in its role in Arushi Murder case. The concept of media trial is not a new concept. The role of media was debated in the PriyadarshiniMattoo case, Jessica Lal Murder Case and likewise many other high profile cases. There have been numerous instances in which media has been accused of conducting the trial of the accused and passing the 'verdict' even before the court passes its judgment. Trial is essentially a process to be carried out by the courts. The trial by media is definitely an undue interference in the process of justice delivery. Before delving into the issue of justifiability of media trial it would be pertinent to first try to define what actually the 'trial by media' means. Trial is a word which is associated with the process of justice. It is the essential component on any judicial system that the accused should receive a fair trial.

Media has now reincarnated itself into a 'public court' (JantaAdalat) and has started interfering into court proceedings. ${ }^{1}$ It completely overlooks the vital gap between an accused and a convict keeping at stake the golden principles of 'presumption of innocence until proven guilty' and 'guilt beyond reasonable doubt'. Now, what we observe is media trial where the media itself does a separate investigation, builds a public opinion against the accused even before the court takes cognizance of the case. By this way, it prejudices the public and sometimes even judges and as a result the accused, that should be assumed innocent, is presumed as a criminal leaving all his rights and liberty unrepressed. If excessive publicity in the media about a suspect or an accused before trial prejudices a fair trial or results in characterizing him as a person who had indeed committed the crime, it amounts to undue interference with the "administration of justice", calling for proceedings for contempt of court against the media. Unfortunately, rules designed to regulate journalistic conduct are inadequate to prevent the encroachment of civil rights.

\footnotetext{
${ }^{1}$ Tripathi, Devesh, “Trial by Media: Prejudicing the Sub Judice”, RMLNLU Journal, Lucknow, 2015, p.1.
} 
Freedom of the media is indeed an integral part of the freedom of expression and is an essential requisite of a democratic set up. The Indian Constitution has granted this freedom by way of Fundamental Rights. The media, which is obligated to respect the rights of individuals, is also obligated to work within the framework of legal principles and statutes. These principles/statutes have been framed by way of minimum standards and do not intend to detract from higher standards of protection to the freedom of expression.

The media is the Fourth limb of a democratic system, the legislature, executive and judiciary being the other three. While legislature prepares the law for the society and the executive takes steps for implementing them, the third stepping-stone is the judiciary, which has to ensure legality of all actions and decisions. The Fourth Estate i.e. the press has to operate within the framework of these statutes and constitutional provision to act in public and national interest. This is indicative of the fact that nobody is above law. When the Constitution of India guaranteed freedom of expression and speech to its citizens, it ensured that the freedom was not absolute and any expression, by way of words, speech or visual medium, did not violate any statutory provisions enacted by legislature and executed by the executive. If the media, electronic or print, exceeded its jurisdiction, the courts came forward to ensure that violation of the Fundamental rights by the media does not go unchecked.

\section{ORIGIN OF THE WORD 'TRIAL BY MEDIA':-}

Trial by media is a phrase popular in the late 20th century and early $21^{\text {st }}$ century to describe the impact of television and newspaper coverage on a person's reputation by creating a widespread perception of guilt or innocence before, or after, a verdict in a court of law. Its first inception was the phrase Trial by Television which found light in the response to the $3^{\text {rd }}$ February, 1967 television broadcast of The Frost Programme, host David Frost. The confrontation and Frost's personal adversarial line of questioning of insurance fraudster Emil Savundra led to concern from ITV executives that it might affect Savundra's right to a fair trial.

During high-publicity court cases, the media are often accused of provoking an atmosphere of public hysteria akin to a lynch mob which not only makes a fair trial nearly impossible but means that regardless of the result of the trial the accused will not be able to live the rest of their life without intense public scrutiny.

The counter-argument is that the mob mentality exists independently of the media which merely voices the opinions which the public already has.

Although a recently coined phrase, the idea that popular media can have a strong influence on the legal process goes back certainly to the advent of the printing press and probably much further. This is not including the use of a state controlled press to criminalize political opponents, but in its commonly understood meaning covers all occasions where the reputation of a person has been drastically affected by ostensibly non-political publications.

Often the coverage in the press can be said to reflect the views of the person in the street. However, more credibility is generally given to printed material than 'water cooler gossip'. The responsibility of the press to confirm reports and leaks about individuals being tried has come under increasing scrutiny and journalists are calling for higher standards. There was much debate over U.S President Bill Clinton's impeachment trial and prosecutor Kenneth Starr's investigation and how the media handled the trial by reporting commentary from lawyers which influenced public opinion. ${ }^{2}$

In the United Kingdom, strict contempt of court regulations restrict the media's reporting of legal proceedings after a person is formally arrested. These rules are designed so that a defendant receives a fair trial in front of a jury that has not been tainted by prior media coverage. The newspapers the Daily Mirror and the The Sun have been prosecuted under these regulations, although such prosecutions are rare. ${ }^{3}$

Trial by media emerged as a term of colloquial origin, indicating perhaps the media's assignment to itself the adjudicatory process. The media is often found publishing opinion and spreading prejudice under the grab of 'news'. Owing to the colloquial origin of the term, there exists no comprehensive definition. The Hon'ble Supreme Court has made an attempt in R K Anand to define the term in the following manner: "The impact of television and newspaper coverage on a person's reputation by creating a widespread perception of guilt regardless of any verdict

2“"Legal News: News Hour with Jim Lehrer" (Transcript).Public Broadcasting System (PBS). $19^{\text {th }}$ October, 1998. ${ }^{3}$ Bowcott, Owen, "Contempt of court rules are designed to avoid trial by media", The Guardian, $5^{\text {th }}$ July, 2011. 
in a court of law. During high publicity court cases, the media are often accused of provoking an atmosphere of public hysteria akin to a lynch mob which not only makes a fair trial nearly impossible but means that, regardless of the result of the trial, in public perception the accused is already held guilty and would not be able to live the rest of their life without intense public scrutiny."4

F. S. Nariman, the noted jurist, had once observed, "A responsible Press is the handmaiden of effective judicial administration. The Press does not simply publish information about cases and trials but, subjects the entire Justice hierarchy (police, prosecutors, lawyers, Judges, Courts), as well as the judicial processes, to public scrutiny. Free and robust reporting, criticism and debate contribute to public understanding of the rule of law, and to a better comprehension of the entire Justice - system. It also helps improve the quality of that system by subjecting it to the cleansing effect of exposure and public accountability." great a need that courts be allowed to do their duty fearlessly.

C.P. Scott, the founder editor of the Manchester Guardian, once said: "Comment is free but facts are sacred". 6 In India, news in a written format had always been considered the truth and has been more powerful than the spoken word. But such position is not in existence anymore. The media is an integral and imperative component of democratic polity and is rightly called fourth limb of democracy. It is not merely what the media does in a democracy, but what it is, that defines the latter. Its practice, its maturity, and the level of ethics it professes and practices in its working are as definitive of the quality of a democracy as are the functions of the other limbs. With tremendous growth and expansion, prospects of mass media are today viewed as more powerful than ever before.

There are numerous cases in which media has played vital role in discovering evidence, or properly analyzing witnesses and helped judiciary to meet ends of justice. This indispensible role of Media has made it Fourth pillar of democracy. But independent investigation of media into crime has been harshly criticized at many times and non interference with work of judiciary is encouraged. This paper aims to look into the aspects where media act as defendant for various charges raised against it regarding its work, accountability, interference and functioning.

In India, the media have played a historical role in providing information to the people about social and economic evils. The media have informed the public about the tremendous poverty in the country, the suicide of farmers in various States, the so called honour killing in many places by KhapPanchayats, corruption and so on. However, the media have a great responsibility also to see that the news they present is accurate and serve the interest of the people. If the media convey false news that may harm the reputation of a person or a section of society, it may do great damage since reputation of a valuable asset for a person. Even if the media subsequently correct a statement, the damage done by it may be irreparable. Hence, the media should take care and carefully investigate any news item before reporting it.

\section{History:-}

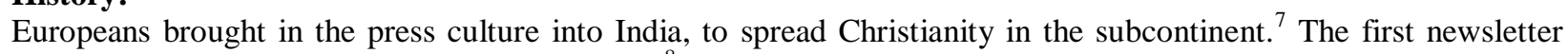
was started by James Augustus Hikey in $1780 .{ }^{8}$ The British government was not keen on this because being in English it wouldn't really incite people, but anyhow due to some defamation charges Hickey was stopped. In 1799, the first act pertaining to press was passed that was the Lord Wellesley's Press Act. ${ }^{9}$ The act had provisions for pre censorship where in every newspaper was first inspected by the government secretary and then published. On insistence with the act the offender was deported back to Europe. A Press Act ${ }^{10}$ passed in 1813 which regulated publishing pertaining to the military. In 1818, another press act was passed related to censorship of articles relating to peace and tranquillity. The licensing regulation and Metcalf's act were also there. The actual strict regulations on press began after the mutiny of 1857 where in stringent laws were put in so that incitement to Indian people was avoided. The Vernacular Press $\mathrm{Act}^{11}$ was passed so that no papers could be published in a language the British had a

\footnotetext{
${ }^{4}$ R.K Anand v. Registrar, Delhi High Court (2009) 8 SCC 106.

5“Media and the Law" Seminar, University Law College, VidhiBhawan, University of Rajasthan on $27^{\text {th }}$ May 2006.

${ }^{6}$ Scott, C. P., 1846-1932: the making of the Manchester Guardian, Frederick Muller, London, 1946.

${ }^{7}$ Primrose, J.B., The library, Dec. 1939, vol XX, No.3, p. 245.

${ }^{8}$ Hickey, William, The memoirs of William Hickey Vol II (1775-1782), Hurst and Blackett, London, 1918, p.175

${ }^{9}$ Metcalf's Act IX, 1835.

${ }^{10}$ Press Act, 1813.

${ }^{11}$ Vernacular Press Act, 1878.
} 
problem in interpreting. The Indian National Congress and other ardent libertarians took to a more assertive and insightful media. After the independence freedom to the press and media was welcomed by the leaders. The major burden that was put on media was at the time of Emergency. Since then Indian media has had a fairly good relationship with their rights.

One of the first celebrities in the $20^{\text {th }}$ century to be arguably tried by media was Roscoe 'Fatty' Arbuckle who was acquitted by the courts but nevertheless lost his career and reputation due to the media coverage. Parallels can be drawn between these cases and the trial of O.J. Simpson. The connection is less about guilt or innocence but about the promotion of the media coverage in the public mind above the status of the court. Another interesting case in the US was the Rodney King incident and subsequent trial of the police officers involved. Once again, an acquittal is challenged by the media reporting with violent consequences. What makes this case particularly important historically is the fact that it was amateur video footage which provided the key evidence of perceived guilt. As video cameras and their digital successors and CCTV become wider spread, this type of 'caught on camera' incident become more and more common. This can pose real problems for the legal system as the evidence they provide may be inadmissible for technical reasons (e.g. not being able to pinpoint exact times) but they give very strong images for the media (and public) to seize upon and the potential to manipulate by editing.

Even where a criminal court finds somebody guilty the media can still appear to sit in judgment over their sentence. Examples include Myra Hindley whose proposed release from prison after thirty years was widely condemned by the British press (the argument became moot when she died in 2002); Maxine Carr who, having served her sentence, has been released and is, according to some commentators being "demonised by the press". One case popularized by the media between 1980 and 1982 was the murder trial of Lindy Chamberlain in Australia who was, but later released in 1986 on new evidence showing that a dingo had in fact committed the act as was originally claimed by Chamberlain. The motion picture 'A Cry in the Dark' depicted Chamberlain, as played by actress Meryl Streep, caught in a "trial by media" which fed the public's, and subsequently the jury's false conviction of her.

Often the coverage in the press can be said to reflect the views of the person in the street. However, more credibility is generally given to printed material than 'water cooler gossip'. The responsibility of the press to confirm reports and leaks about individuals being tried has come under increasing scrutiny and journalists are calling for higher standards. There was much debate over U.S President Bill Clinton's impeachment trial and prosecutor Kenneth Starr's investigation and how the media handled the trial by reporting commentary from lawyers which influenced public opinion. Another example was the investigation into biologist Steven Hatfill allegedly sending anthrax through the U.S. mail as a terrorist attack, which resulted in no conviction, but Hatfill went on to sue as his reputation was severely tarnished and career destroyed.

Families and friends of persons convicted of crimes have apparently successfully used the power of the media to reopen cases, such as the Stephen Downing case in Derbyshire where a campaign by a local newspaper editor resulted in a successful appeal and his release after twenty seven years in prison.

\section{International Prospective:-}

The media has been called the handmaiden of justice, the watchdog of society; the judiciary, the dispenser of justice and the catalyst for social reforms. Thus, both are essential for the progress of a civil society. In 1807, in the United States of America with the case of Aron Burr United States v. Burr,subsequently, it erupted in England; it has finally reached the shores of India. The Indian judiciary finds itself at a crossroad to balance the competing fundamental rights of the media and of the accused. The United States of America, England and India are the torchbearers of democracy. We are progenies of the common law. We, thus, share a common political ideology, a common legal heritage. The Constitutions, whether written or unwritten, proclaim, protect and promote the same set of fundamental rights.

One of the most important functions of an independent judiciary is to ensure the right to a fair trial. This obligation is enshrined in the 1985 UN Basic Principles on the Independence of the Judiciary, in Article 6, which states the judiciary is entitled and required - to ensure that judicial proceedings are conducted fairly and that the rights of the parties are respected. ${ }^{12}$ The principles enunciated in this Article are also stated in similar language as in the

\footnotetext{
${ }^{12}$ UN Basic Principles on the Independence of the Judiciary, G.A. Res.146, U.N. GAOR, 40th Sess.(1985)art.6.
} 
International Covenant on Civil and Political Rights (ICCPR) ${ }^{13}$, which provides that —everyone shall be entitled to a fair and public hearing by a competent, independent and impartial tribunall in the determination of any criminal charge or in a suit at law. ${ }^{14}$ The ICCPR acknowledges that the right to a public trial is not absolute and that certain limitations on public access are necessary.

In 1994, a group of 39 distinguished legal experts and media representatives met and lead to the development of the Madrid Principles. ${ }^{15}$ The objectives of the meeting were, to examine the relationship between the media and judicial independence, to formulate principles to help the media and the judiciary and develop a relationship that serves both freedom of the expression and the judicial independence.

Section 10 of the Madrid Principles outlines permissible limits on the freedom of expression: 10. Laws may restrict the Basic Principle [of a free press] in relation to criminal proceedings in the interest of the administration of justice to the extent necessary in a democratic society a) for the prevention of serious prejudice to a defendant; b) for the prevention of serious harm to or improper pressure being placed upon a witness, a member of a jury, or a victim

\section{Impact Of Media Trials:-}

1. Media trials vs. Freedom of speech and expression

"The press is commercialized to a large extent. In this business, profits and social responsibility need to be balanced and if that does not happen, society will not accept the media for long. As an independent and statutory body, the PCI shall ensure that a balance is struck between profit-making and social responsibility, profit-making tendency of some media owners and contractual-basis hiring of journalists are hampering quality of journalism." - Justice MarkandeyKatju, (former Judge, Supreme Court of India), Former Chairman, Press Council of India

The freedom of the press stems from the right of the public in a democracy to be involved on the issues of the day, which affects them. Media has now reincarnated itself into a public court (JantaAdalat) and has started interfering in to court proceeding. When the media divulges on the legal process, freedoms and privileges collide. Media sort off attains formal prerogative powers to decide the cases and make them look true in the eyes of public. The media being the mainstay of the news industry, a piece of and all probable information whichever comes to hand that the general receives regarding an incident is looked under the media's spectacles and then conveyed through the mouth piece that is the media itself, proclaiming its prospect as just trials. Authenticity of such information is a sort after quest and to what extent should the public get convinced by it lands the public in a rather muddle plight. An accused's right to a fair trial and the media's right to freedom of expression are in frequent tension. The principle agents of these rights, the media and the judiciary are interdependent proponents of constitutional rights, often in conflict as to where the priority and emphases should be placed in the free press v. fair trial dichotomy; the tension between the two is an inevitable and perhaps necessary one. ${ }^{16}$

The Hon'ble Supreme Court of India has observed that the freedom of press is regarded as - the mother of all liberties in a democratic society. ${ }^{17}$ But the question of worry is what happens when the news provided to the public through media and subsequently through judicial process is incompatible?

Public naturally would believe what they are sold by an upper hand authority like the media. According to criminal jurisprudence, a suspect is entitled to a fair trial and is presumed to be innocent till proven guilty by a Court of law. None can be allowed to prejudge or prejudice his case till the completion of trial. However, media on account of excessive coverage goes beyond its domain and publishes and covers interviews of witness or relative of a victim and prejudges the issue of conviction of the accused while the matter is pending adjudication in a court of law. This has a tendency to prejudice the mind of Court, prosecutor and general public at large. But thereby there lies a

\footnotetext{
${ }^{13}$ Adopted and opened for signature, ratification and accession by General Assembly Resolution 2200 A (XXI) of 16 December 1966. Entered into force on 23 March 1976 in accordance with article 49.4.

${ }^{14}$ Art. 14(1), ICCPR, (1966) 999 UNTS 171, 1976 Can. T.S. No. 47, in force, including Canada, 1976.

${ }^{15}$ The Madrid Principles on the Relationship between the Media and Judicial Independence, established by a group convened by the International Commission of Jurists, its Centre for the Independence of Judges and Lawyers, and the Spanish Committee of UNICEF.

${ }^{16}$ Effect of trial by media before courts.Available at http://www.lawteacher.net/commercial-law/essays/effect-oftrial-by-media-before-courts-lawessay.php.

${ }^{17}$ Harijai Singh and Vijayakumar, AIR 1997 SC 73.
} 
minimal expectation from media to conform to their jurisdiction of affairs and ensure that what they convey is free of bias. Lately, the media has not only dared to operate outside its bounds but also reach a point where they assume the role of the judiciary in being decisive for the cases. ${ }^{18}$

Art. 19(1)(a) of the Constitution of India guarantees, freedom of speech and expression and Art. 19(2) permits reasonable restrictions to be imposed. However Article 19(2) does not refer to 'administration of justice' but interference of administration of justice is clearly referred to in the definition of 'criminal contempt' in Sec. 2 of the Contempt of Courts Act,1971 and in Sec. 3 thereof as amounting to contempt. Therefore, publications/coverage which interfere or tend to interfere with the administration of justice amount to criminal contempt under the Contempt of Court Act and if in order to preclude such interference, the provisions of that Act impose reasonable restrictions on freedom of speech, such restrictions would be valid.

In Maxwell, the Court prescribed certain methods for controlling the pre-trial publicity ${ }^{19}$ :

(i) Control the presence of the press at the judicial proceedings.

(ii) The court should have insulated the witnesses. This implies protecting and isolating the witnesses during the trial.

(iii) The court should make efforts to control the release of leads, information, and gossip to the press by police officers, witnesses, and the counsel for both sides. More specifically, the trial court might well have proscribed extrajudicial statements by any lawyer, party, witness, or court official which divulged prejudicial matter.

(iv) Reporters who wrote or broadcast prejudicial stories could have been warned as to the impropriety of publishing material not introduced in the proceedings.

(v) Where there is a reasonable likelihood that prejudicial news prior to trial will prevent a fair trial, the judge should continue the case until the threat abates, or transfer it to another county not so permeated with publicity.

(vi) If publicity during the proceedings threatens the fairness of the trial, a new trial should be ordered.

Media substitutes the role of the judiciary by indulging in concepts of - breaking news, carrying on investigation of crimes, interfering in police investigation and partial reporting. ${ }^{20}$ In the recent past, few media driven cases include the Arushi murder case, Jessica Lal murder case, BMW accident case, Nirbhaya rape case, NiraRadia case. Apart from this there were scams like the 2G scam, Bofors scam, Commonwealth Games scam and Harshad Mehta stock market scam. All these cases pertain to various diverse fields but do share a common ground of being driven by the media. This takes us back to the question raised in the very beginning; how much interference may be passed off as the work of a healthy regulator and when does it start to interfere with the process of the court. However, it needs to be appreciated that Media also plays a good role while divulging corruption in government exchequer and in bringing out the government's inaction on many occasion to the lime light and eventually action is taken. But at the same time, conflicts arise when media transgresses its domain and tries to usurp the power of judiciary and make judgmental comments on pending trials.

But balancing between the rights of people to know and presumption of the accused to be innocent till he is found guilty by a competent court, has become inevitable but neck to neck competition regarding publication and coverage among various media houses having a tendency to interfere with administration of justice has become matter of concern for legislature as well as judiciary. ${ }^{21}$ Under Article 19(1)(a) of the Constitution, the rights of the freedom of Press have been recognized as Fundamental Rights and under Article 21 of the Constitution the suspect and under trial and the Civil litigant have Fundamental Right to have a free and fair trial. ${ }^{22}$ Thereby, balancing between the two fundamental rights has become inevitable and the time has come that Courts should give appropriate directions with regard to reporting of matters, in electronic and print Media, which are sub judice. When rights of equal weight clash, Courts have to evolve balancing measures based on re-calibration under which both the rights are given equal

\footnotetext{
18 "Enact law to regulate trial by media: Law Commission", The Hindu, $3^{\text {rd }}$ Sept, 2006.

${ }^{19}$ Indian Express Newspapers V Union of India 1985 SCR (2) 287.

${ }^{20}$ S.L Rao, "Trial by Media-Television should have no role when criminal cases are in court", The Telegraph, $25^{\text {th }}$ July, 2011. Available at http://www.telegraphindia.com/1110725/jsp/opinion/story_14234123.jsp.

${ }^{21}$ The Blanket, Journal of Protest and Dissent, November 2000.

${ }^{22}$ Maneka Gandhi Vs Union Of India 1978 SCR (2) 621.
} 
space in the Constitutional Scheme. In the Constitution of the United States of America, freedom of press is absolute and any interference with right of media to report, comment upon pending trial is illegal. ${ }^{23}$

\section{Impact Of Media Trial On The Judicial Proceedings:-}

"No one killed Jessica", "Dr. Talwar responsible for murdering daughter Aarushi", "Sen charged for sedition, Ram JethMalani may take his case". These are few headlines which can easily be found while browsing news channels. But these are not mere headlines; this is what is served to public by media with garnishing of interpretation and exaggeration which will add to their TRP. But the question arises is that to what extent Media is responsible and accountable to people. Apart from these cases, there were other issues like $2 \mathrm{G}$ scam, Bofors scam, Commonwealth Games scam and Harshad Mehta stock market scam which do share a common ground of being driven by the media. This takes us to a very important question that how much interference may be passed off as the work of a healthy regulator and when does it begin to interfere with the process of the court.

The most important tool that the media has is the tool of influence it has on people. It is the ideology of the editor and the publisher that reach to masses. This ideology can be such that it incites and manoeuvres the thought of the receivers. It can also be very easily funded to shape any kind of thought to anything. The power to influence people, which the media has springs from the right to speech and expression ${ }^{24}$, unlike other countries ${ }^{25}$, India does not have explicit speech and expression rights for the media. The ambit of the right is huge and includes propagation and proliferation of any kind of ideas. But the right has certain sanctions which say that this right cannot go ahead to put in danger or be inconsistent with the sovereignty and integrity of India, security of the state, friendly relations with other states, public order, decency and morality, contempt of court, defamation or incitement of an offence. ${ }^{26}$ It is very important for the media to not over exercise its powers. As the media did in the case of the 26/11 attacks. Even though such provisions exist the media holds significant power and can distort the way in which judicial proceeding function

Distortion of facts has remained the most widely used shield that it is the right to speech that the media holds. Another counter contention also remains that the esteem of the judiciary should remain high and must not be easily provoked by the right to speech of expression of the media. The esteem of the judiciary should not be questioned but it should rather be seen that the function of the judiciary is only till the boundaries of law; it cannot in any manner work upon the facts. The media holds the power that it can distort the facts and hence decide the case for itself, committing a contempt of court.

The evidences to be presented in the court of law need to be such that prove the innocence beyond reasonable doubt. ${ }^{27}$ What is reasonable doubt depends on case to case and differs from case to case. Reasonableness usually depends upon the prudence of a human being. ${ }^{28}$ Reasonableness is the used to decide the actual bone of contention in a case. Due to this reasonableness the Court may presume existence of certain facts. The Court may presume the existence of any fact which it thinks likely to have happened, regard being had to the common course of natural events, human conduct and public and private business, in their relation to the facts of the particular case. ${ }^{29}$ It is very important to notice that the court is at power to assume some facts of a case. If the media proliferates one common belief in the people and facts are hence are assumed to be like that by the court, given the popular perception it will in a manner mean that the case has been decided by the media.

The power of press can also be understood in the basis of how the people respond and react to the news. In few cases media has been quite powerful in forming public opinion. Jessica Lal and PriyadarshiniMattoo cases are the positive example of role of media in order to meet with ends of justice. There was widespread outrage and protests after both the murder cases were reported. People had realized that justice had been denied and it was necessary to protest and speak aloud. Both the cases involved high-profile people and this fact made the people all the more

23 Tony Rogers, The First Amendment and Press Freedom. Available at http://journalism.about.com/od/ethicsprofessionalism/a/firstamen.htm/

${ }^{24} \mathrm{Ar} .19(1)(\mathrm{a})$ constitution of India.

${ }^{25}$ I st amendment, Constitution of America.

${ }^{26} \mathrm{Ar} .19$ (2) constitution of India.

${ }^{27}$ Dahyabhai v. state of Gujarat ,AIR 1964 SC 1563.

${ }^{28}$ Section 3, The Indian Evidence Act, 1872

${ }^{29}$ Section 114 Indian evidence act 1872 
interested and aware of the proceedings of the cases. We see that media interference helped in the rightful and proper closure of the case. The two murder cases are classic examples of reactive and responsible journalism which helped citizens get their right.

\section{International Perspective:-}

One of the most important functions of an independent judiciary is to ensure the right to a fair trial. This obligation is enshrined in the 1985 UN Basic Principles on the Independence of the Judiciary, at Article 6, which states the judiciary is entitled and required "to ensure that judicial proceedings are conducted fairly and that the rights of the parties are respected." 30 The principles enunciated in this Article are also stated in similar language in the International Covenant on Civil and Political Rights (ICCPR) ${ }^{31}$, which provides that "everyone shall be entitled to a fair and public hearing by a competent, independent and impartial tribunal" in the determination of any criminal charge or in a suit at law. ${ }^{32}$

Article 19 of ICCPR $^{33}$ confirms that freedom of expression is also a fundamental part of a democratic society. It elaborates that freedom of expression includes the freedom of the press and states that "[e]veryone shall have the right to freedom of expression; this right shall include freedom to seek, receive and impart information and ideas of all kinds, regardless of frontiers, either orally, in writing or in print, in the form of art, or through any other media of his choice." It seems clear that this right as expressed would include an individual's right, including that of a media employee, to impart information to the public by writing, broadcasting and by television.

\section{Legal Implications Of Media Trial:-}

\section{a. Freedom of Speech and Expression}

Article 19 of the International Convent on Civil Rights, $1966^{34}$, embodied the right to freedom of Speech, that is, "everyone shall have the right to hold opinions without interference" and the "freedom to seek, receive and impact information and ideas of all kinds, regardless of frontier, either orally, in writing or in print, in the form of art, or through any other media of his choice."35

Article 19(1)(a) of Indian constitution guarantees to all citizens the right to freedom of Speech and Expression. Freedom of Speech and Expression includes within its scope the freedom of the press. To maintain the importance of Freedom of Press, The Hon'ble Court observed that there can be no doubt that freedom of speech and expression includes freedom of propagation of ideas, and that freedom is ensured by the freedom of circulation. ${ }^{36}$ The Supreme Court also held in BrijBhushanvs State of Delhi ${ }^{37}$ that "there can be little doubt that the imposition of pre-censorship on a journal is a restriction on the liberty of the press which is an essential part of the right to freedom of Speech and Expression under Article 19(1) (a)..... Every free man has an undoubted right to lay what sentiments he pleases before the public; to forbid this, is to destroy of the press."

${ }^{30}$ UN Basic Principles on the Independence of the Judiciary, G.A. Res.146, U.N. GAOR, 40th Sess.(1985) art.6.

31 Adopted and opened for signature, ratification and accession by General Assembly Resolution 2200 A (XXI) of 16 December 1966. Entered into force on 23 March 1976 in accordance with article 49.

32 Art. 14(1), ICCPR, (1966) 999 UNTS 171, 1976 Can. T.S. No. 47, in force, including Canada, 1976 (my emphases).

${ }^{33}$ As well as Article 10 of the European Convention on Human Rights (ECHR).

${ }^{34}$ International Covenant on Civil and Political Rights, 1966, Adopted and opened for signature, ratification and accession by General Assembly resolution 2200A (XXI) of 16 December 1966, entry into force 23 March 1976.

${ }^{35}$ Article 19 of the International Covenant on Civil and Political Rights, 1966: 1. Everyone shall have the right to hold opinions without interference. 2. Everyone shall have the right to freedom of expression; this right shall include freedom to seek, receive and impart information and ideas of all kinds, regardless of frontiers, either orally, in writing or in print, in the form of art, or through any other media of his choice. 3. The exercise of the rights provided for in paragraph 2 of this article carries with it special duties and responsibilities. It may therefore be subject to certain restrictions, but these shall only be such as are provided by law and are necessary: (a) For respect of the rights or reputations of others; (b) For the protection of national security or of public order (ordre public), or of public health or morals.

${ }^{36}$ RomeshThapper v. State of Madras AIR 1950124 (Supreme Court of India).

${ }^{37}$ AIR 1950 SC 129. 
It must be borne in the mind that the Constitution must be interpreted in a broad way and not in a narrow and pedantic sense. Certain rights have been enshrined in our Constitution as fundamental and, therefore, while considering the nature and content of those rights the Court must not be too astute to interpret the language of the Constitution in so literal sense as to whittle them down. On the other hand the court must interpret the Constitution in a manner which would enable the citizen to enjoy the rights guaranteed by it in the fullest measures subject, of course, to permissible restrictions. ${ }^{38}$ Bearing this principle in mind it would be clear that the right to Freedom of Speech and Expression carries with, it the right to publish and circulate the ideas, opinions and views with complete freedom and by resorting to any available means of publication, subject again to such restrictions as could be legitimately imposed under Article 19(2). The first decision of this court in which this was recognised is RomeshThappar vs. State of Madras. ${ }^{39}$ There this Court held that freedom of Speech and Expression includes freedom of propagation of ideas and that this freedom is ensured by the freedom of circulation.

\section{b. Media vs. Right to Privacy}

"Civilization is the progress towards a society of privacy. The savage's whole existence is public, rule by the laws of his tribe. Civilization is the progress of setting man free from man." 40

Article 12 of the Universal Declaration of Human Rights (1948) defines privacy in the following terms: "No one shall be subjected to arbitrary interference with his privacy, family, home or correspondence nor to attacks upon his honor and reputation. Everyone has the right to the protection of the law against such interference or attacks."

The law of privacy is recognition of the individual's right to be let alone and to have his personal space inviolate. The need for privacy and its recognition as a right is a modern phenomenon. It is a product of an increasingly individualistic society in which the focus has been shifted from society to the individual.

The right to freedom of Speech and Expression and the right to privacy are two sides of the same coin. One person's right to know and be informed may violate another's right to be left alone. The exponential growth of media, particularly the electronic media in recent years has brought into focus issues of privacy. The media has made it possible to bring the private life of an individual into the public domain, exposing him to the risk of an invasion of his space and privacy.

In India, the right to privacy is not a specific fundamental right but has nevertheless gained constitutional recognition. 'Privacy' is not enumerated amongst the various reasonable restrictions to the right to freedom of Speech and Expression enlisted under Article 19(2). However, this lacuna has not prevented the court carving out a constitutional right to privacy by a creative interpretation of the right to life under Article 21 and the right to freedom of movement under Article 19(1)(d).

The first case related to right to privacy was Kharak Singh vs. State of U.P. ${ }^{41}$ In this case the majority were unreceptive to the idea of recognising a right to privacy and dismissed the claim on the ground that there could be no fundamental right to protect 'mere personal sensitiveness'. But subsequently, the Court acknowledged a limited right to privacy in the case of Govind vs. State of M.P. ${ }^{42}$ The Supreme Court touched the rights of the individual to privacy vis-à-vis invasions by journalists in SheelaBarse vs. Union of India ${ }^{43}$, PrabhaDutt vs. Union of India ${ }^{44}$ and also in State vs. Charulata Joshi. ${ }^{45}$ In all these cases, journalists sought permission from the Supreme Court to interview and photograph the prisoners. Although, the issue of privacy was not directly dealt with, the court implicitly acknowledged the right to privacy by holding that the press has no absolute right to interview or photograph a prisoner but could do so only with his consent.

\footnotetext{
${ }^{38}$ Article $19(2)$ of the Constitution of India.

${ }^{39}$ AIR 1950 SC 124.

${ }^{40}$ Ayn Rand, The Fountainhead, (1943).

${ }^{41}$ AIR 1963 SC 1295.

${ }^{42}$ (1975) 2 SCC 148: 1975 SCC (Cri) 468.

${ }^{43}(1987) 4$ SCC 373.

${ }^{44}(1982) 1$ SCC 1.

${ }^{45}$ (1999) 4 SCC 65.
} 


\section{Regulatory Measures:-}

There are various ways to regulate the media like the Press Council of India (PCI) was established to preserve the freedom of the press and to improve the standards of news reporting in India. Under the Press Council Act 1978, if someone believes that a news agency has committed any professional misconduct, the PCI can, emphasise the importance of accuracy and fairness and encourages the press to "eschew publication of inaccurate, baseless, graceless, misleading or distorted material." The norms urge that any criticism of the judiciary should be published with great caution. These norms further recommend that reporters should avoid one-sided inferences, and attempt to maintain an impartial and sober tone at all times. But significantly, these norms cannot be legally enforced, and are largely observed in breach. Lastly, the PCI also has criminal contempt powers to restrict the publication of prejudicial media reports. However, the PCI can only exercise its contempt powers with respect to pending civil or criminal cases. This limitation overlooks the extent to which pretrial reporting can impact the administration of justice.

The Hon'ble Supreme of India in the matter, Sahara India Real Estate Corporation Ltd. and Ors. Vs. Securities and Exchange Board of India and Anr (2012)10SCC603, constituted a five judge Constitution Bench when during the pendency of appeal. Despite the interim order of the Court, some of the news papers published the proceedings of the judgment. The Court laid down appropriate guidelines with regard to reporting media of matters which is sub judice in Court including public disclosure of documents forming part of Court proceedings and also the manner and extent of publicity to be given by media of pleadings filed in proceeding in Court which are pending and not yet adjudicated upon and the court suggested various measures.

The most reckoning research on the positive and negative aspects of media trial has been elaborated in 200th report of the Law Commission entitled Trial by Media: Free Speech vs. Fair Trial Under Criminal Procedure (Amendments to the Contempt of Court Act, 1971) that has made recommendations to address the damaging effect of sensationalized news reports on the administration of justice. While the report has yet to be made public, news reports indicate that the Commission has recommended prohibiting publication of anything that is prejudicial towards the accused - a restriction that shall operate from the time of arrest. It also reportedly recommends that the High Court be empowered to direct postponement of publication or telecast in criminal cases. The report noted that at present, under Section 3 (2) of the Contempt of Court Act, such publications would be contempt only if a charge sheet had been filed in a criminal case. The Commission has suggested that the starting point of a criminal case should be from the time of arrest of an accused and not from the time of filing of the charge sheet. In the perception of the Commission such an amendment would prevent the media from prejudging or prejudicing the case.

Another controversial recommendation suggested was to empower the High Court to direct a print or an electronic media to postpone publication or telecast pertaining to a criminal case and to restrain the media from resorting to such publication or telecast. The 17 th Law Commission has made recommendations to the Centre to enact a law to prevent the media from reporting anything prejudicial to the rights of the accused in criminal cases from the time of arrest, during investigation and trial. Second ARC has also recommended for a code of conduct for the media.

\section{Conclusion:-}

The print and electronic media have gone into fierce and ruthless competition, as we call them 'aggressive journalism' that a multitude of cameras are flashed at the suspects or the accused and the police are not even allowed to take the suspects or accused from their transport vehicles into the courts or vice versa. Earlier, journalism was not under pressure to push up TRP ratings or sales. So the journalists did their work with serious intent and conviction, with courage and integrity. They did not pronounce people guilty without making a serious attempt to study the charges, investigate them, and come to their own independent conclusions, without fear or favour. They did not blindly print what law enforcers claimed, what the bureaucracy said or what politicians planted on to them. That is why people trusted them. But now we are seeing a different self-acquired role of media in form of 'media trial'. Everyone manipulates the media to serve their own interests or hurt their rivals. The problem does not lie in media's exposing the lacuna of a bad investigation by police, or mal-performance of the duties ordained to the civil servants but the eye-brows start to raise when the media ultra vires its legitimate jurisdiction and does what it must not do. Be it highlighting the sub-judice issues into public keeping at stake the sanctity of judicial procedures and 'right to life with dignity' of accused and suspects. The media trial has now moved on to media verdict and media punishment which is no doubt an illegitimate use of freedom and transgressing the prudent demarcation of legal boundaries. 
From the above account, it becomes clear that the media had a more negative influence rather than a positive effect. The media has to be properly regulated by the courts. The media cannot be granted a free hand in the court proceedings as they are not some sporting event. Any institution, be it legislature, executive, judiciary or bureaucracy, is liable to be abused if it exceeds its legitimate jurisdiction and functions. Media trial is also an appreciable effort along with the revolutionary sting operations as it keeps a close watch over the investigations and activities of police administration and executive. But there must be a reasonable self-restriction or some sort of regulations over its arena and due emphasis should be given to the fair trial and court procedures must be respected with adequate sense of responsibility. Media should acknowledge the fact that whatever they publish has a great impact over the spectator. Therefore, it is the moral duty of media to show the truth and that too at the right time. The most suitable way to regulate the media will be to exercise the contempt jurisdiction of the court to punish those who violate the basic code of conduct. The use of contempt powers against the media channels and newspapers by courts have been approved by the Supreme Court in a number of cases.

\section{References:-}

1. Tripathi, Devesh, "Trial by Media: Prejudicing the Sub Judice", RMLNLU Journal, Lucknow, 2015, p.1.

2. "Legal News: News Hour with Jim Lehrer" (Transcript).Public Broadcasting System (PBS). $19^{\text {th }}$ October, 1998.

3. Bowcott, Owen, "Contempt of court rules are designed to avoid trial by media", The Guardian, $5^{\text {th }}$ July, 2011.

4. R.K Anand v. Registrar, Delhi High Court (2009) 8 SCC 106.

5. "Media and the Law" Seminar, University Law College, VidhiBhawan, University of Rajasthan on $27^{\text {th }}$ May 2006.

6. Scott, C. P., 1846-1932: the making of the Manchester Guardian, Frederick Muller, London, 1946.

7. Primrose, J.B., The library, Dec. 1939, vol XX, No.3, p. 245.

8. Hickey, William, The memoirs of William Hickey Vol II (1775-1782), Hurst and Blackett, London, 1918, p.175

9. Metcalf's Act IX, 1835.

10. Press Act, 1813.

11. Vernacular Press Act, 1878.

12. Effect of trial by media before courts.Available at http://www.lawteacher.net/commercial-law/essays/effect-oftrial-by-media-before-courts-lawessay.php.

13. Harijai Singh and Vijayakumar, AIR 1997 SC 73.

14. "Enact law to regulate trial by media: Law Commission", The Hindu, $3^{\text {rd }}$ Sept, 2006.

15. Indian Express Newspapers V Union of India 1985 SCR (2) 287.

16. S.L Rao, "Trial by Media-Television should have no role when criminal cases are in court", The Telegraph, $25^{\text {th }}$ July, 2011. Available at http://www.telegraphindia.com/1110725/jsp/opinion/story_14234123.jsp.

17. The Blanket, Journal of Protest and Dissent, November 2000.

18. Maneka Gandhi Vs Union Of India 1978 SCR (2) 621.

19. Tony Rogers, The First Amendment and Press Freedom. Available at http://journalism.about.com/od/ethicsprofessionalism/a/firstamen.htm/

20. Ar. 19(1)(a) constitution of India.

21. Ist amendment, Constitution of America.

22. Ar. 19(2) constitution of India.

23. Dahyabhai v. state of Gujarat,AIR 1964 SC 1563.

24. Section 3, The Indian Evidence Act, 1872

25. Section 114 Indian evidence act 1872

26. UN Basic Principles on the Independence of the Judiciary, G.A. Res.146, U.N. GAOR, 40th Sess.(1985) art.6.

27. General Assembly Resolution 2200 A (XXI) of 16 December, 1966.

28. Art. 14(1), ICCPR, (1966) 999 UNTS 171, 1976 Can. T.S. No. 47, in force, including Canada, 1976 (my emphases).

29. Article 10 of the European Convention on Human Rights (ECHR).

30. International Covenant on Civil and Political Rights, 1966.

31. Article 19 of the International Covenant on Civil and Political Rights, 1966.

32. RomeshThapper v. State of Madras AIR 1950124 (Supreme Court of India).

33. AIR 1950 SC 129.

34. Article 19(2) of the Constitution of India.

35. AIR 1950 SC 124.

36. Ayn Rand, The Fountainhead, (1943).

37. AIR 1963 SC 1295. 
38. (1975) 2 SCC 148: 1975 SCC (Cri) 468.

39. (1987) 4 SCC 373.

40. (1982) 1 SCC 1.

41. (1999) 4 SCC 65.

42. UN Basic Principles on the Independence of the Judiciary, G.A. Res.146, U.N. GAOR, 40th Sess.(1985)art.6.

43. Art. 14(1), ICCPR, (1966) 999 UNTS 171, 1976 Can. T.S. No. 47, in force, including Canada, 1976. 